УАK (UDC) $241+94(37-11): 271.742: 285.4$

DOI: $10.26565 / 2226-0994-2020-63-13$

Vladyslav Vodko

\title{
THE ERA OF THE MARTYRS IN THE HISTORICAL MEMORY OF THE SYRIAN CHRISTIANS (LATE IV - FIRST HALF OF THE V CENTURY)
}

This research is aimed at studying the nature of Christian Syrians' historical memory about the era of the martyrs on the Syrian territory for the period between the end of the IV century and the first half of the $\mathrm{V}$ century. That was the time when Christianity was developing as the state religion in the Roman Empire. We tried to figure out how the historical memory of the martyrs reflects the peculiarities of the cultural identity of the Syrians and their attitude to representatives of other ethnic groups. It is the first analysis of Syrians' historical memory about the era of the martyrs. It is also a systematic review of the main social and ideological functions that were inherent in Syrians' historical memory about the era of the martyrs (for the period between the late IV century and the first half of the V century). The research resulted in several conclusions about the specificities of the Syrian identity of the designated period. The Christian - Pagan polemic in Syria, in its turn, was considered through the prism of historical memory. Conclusions. The era of early Christian martyrs in Syrian historical memory performed the whole set of cultural, social and ideological functions. The historical memory of the martyrs was an important part of the religious identity of the Syrians who lived on the territory of two warring states, namely Persia and Rome. Representatives of the Syrian church of the designated period emphasized that their church received a significant boost thanks to many martyrs, which became a serious argument in theological disputes and helped to strengthen the regional identity the Antioch school of theology representatives. This school, in its turn, was going through hard times in the 30-40s of V century because of accusations of heresy. The historical memory of the era of the martyrs reflects the issues of the polemic of Christians with their gradually dying paganism (these issues are relevant for the designated period). The texts which constitute a reception of the era of the martyrs often reflect certain socio-economic problems and ethnic contradictions. For instance, Jews are accused of persecuting Christian Syrians in Persia. They say that the Persian ruler increased taxes for Christian Syrians during their persecution. Legends about persecutions in Persia are trying to explain the non-religious causes of persecution and (implicitly) to create some model of behavior that would allow to avoid similar problems for the Christian community in the future.

Keywords: Roman Syria, late antiquity, early Christianity, martyrs, historical memory.

The era of martyrs is a very significant part of the history of Christianity. For the whole centuries, theologians of this denomination were drawing extensively stories about the lives of those who endured torments and died for Christ in favour of their doctrine. The main criterion of holiness for martyrs was a martyrdom that smoothes out all their previous way of life. Thus, the former harlot, the Roman martyr Boniface [Ruinart, 1731, p. 326], who decided to suffer together with Christians when he saw their execution, received wide veneration because of the canonization. A significant part of the information about the martyrs became known for the socalled acts of the Martyrs, i. e. martyrdom acts that were considered to be based on legal records of martyrs' interrogations in Roman courts.

\section{Problem statement}

It is interesting to trace the reception of historical plots relating to the era of martyrdom in different eras. The narrative of martyrs' history changed quite strongly for the period between the late IV century and early V. It was a period when Christianity was actively evolving from a previously persecuted religion to a state and dominant religion. The texts and plots that were previously used to maintain faith became serious elements of the ideological and political struggle and an important part of local historical narratives.

(c) Vodko V. I., 2020.

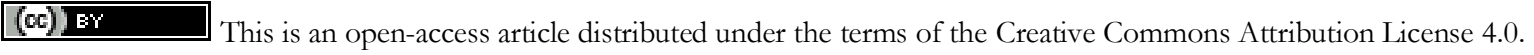


Studying this problem on materials of the eastern provinces of Rome allows to notice some important problems and features of the region, the ideology of its inhabitants, key decisionmakers and church elite.

\section{The analysis of sources and recent researches}

Many studies are devoted to the phenomenon of martyrdom, among which one should single out comprehensive studies of Vasily Bolotov on the history of early Christianity [Bolotov, 1910] and Alexei Lebedev on the era of Christians' persecution in the Roman Empire [Lebedev, 2006]. As for the large body of modern studies on this topic, it is worthy to single out the work of the Romanian researcher Vladimir Ivanovici, who tries to use methods of the new cultural history in studies on the phenomenon of martyrdom [Ivanovici, 2013]. The authors primarily examined the course of events during the persecutions of the times of the ancient church and their context.

\section{The publication's purpose}

The main aim is to clarify how images of the Syrian martyrs were used in the ideological and political struggle in the Syrian provinces for the period between the late IV century and the first half of the $\mathrm{V}$ century.

\section{The statement of the basic material}

A distinctive feature of Syrians' situation of that period is that they lived in two permanently warring empires, namely Persian and Roman. Moreover, while in the Roman Empire Christianity became the state religion (in the reign of Theodosius the Great), in Persia persecution of Christians still occurred sporadically. Thus, for some Syrians, persecution and martyrdom were not exclusively a fact of the past, because they still could become persecuted if they fall from grace of the Persian authorities.

\section{The main sources of this study}

The main sources of this study were created between the IV and V century. Martyrdom of Sharbel [Cureton, 1864c], Barsamya [Cureton, 1864a], Samonas, Gurias, Habib [Cureton, 1864b] and Mar Shimon [Braun, 1915] were reviewed as well as other hagiographic texts [Paykova, 1990b], materials of church sermons [John Chrysostom, 1896a; John Chrysostom, 1896b] and several historical works of thatperiod [Socrates Scholasticus, 1996; Theodoret of Cyrus, 1996].

In the sources, it is possible to notice two very definite traditions, Antiochian and Edessenian. The first one relied on the memory of the Antiochian martyrs of different eras, from Ignatius the God-bearer to those affected by Julian the Apostate Juventin and Maximin. These narratives became the part of the urban myth of Antioch as a city of special Christian piety and feat. At the end of the IV century, these concepts were especially actively promoted by the preacher John Chrysostom, who lived in this city and dedicated the whole set of sermons to the martyrs from Antioch. The Antiochian tradition, despite the proximity of its historical destinies to the fate of other cities in Roman Syria, is quite strongly distinguished by the influence of the Greek-language tradition.

The texts about Edessian martyrs' sufferings were composed mainly in Syriac language. Moreover, the Martyrs have some specific features despite following the common Roman tradition.

The focus of this paper is on the texts of the Edessenian tradition in Syriac. They express precisely the Syrian identity of that period, even to a greater extent than Antioch ones.

In total, there are four known original Syrian martyries [Paykova, 1990a, p. 6]. The first ones are seem to be composed at the end of the IV century, namely the Acts of Samonas, Gurias, and Habib. They became a definite model for the further development of act literature [Meshcherskaya, 1984, p. 5]. Then came the acts of Sharbel and Barsamya which claim to describe the events of the II century. However, they were also compiled for the period between the end of the IV century and the beginning of the $\mathrm{V}$ century. The indicated acts were 
substantially finalized and supplemented by descriptions of events' context even if they were rooted in more ancient texts.

The historical memory of the era of the martyrs is often the historical memory of the era of paganism, which contains a hidden or explicit polemic with it.

This controversy is especially salient in the acts of Sharbel. Sharbel was the main pagan priest of Edessa, who, according to the acts, lived in the era of Emperor Trajan (98-117 AD). As for the king of Osroena, Augar VII, he was the ruler of Edessa at that time. He was dependent on Rome. Trajan, according to the chronology of acts (circa 113-114 AD), began the persecution of Christians in the $15^{\text {th }}$ year of his reign [Cureton, 1864c, p. 41]. The reference to persecutions under Trajan was probably a common point (or literary topos) for the lives of the martyrs, the reason for which was the description of the persecution in Eusebius of Caesarea's Ecclesiastical History. The Early Byzantine historian, as well as the author of the Acts of Sharbel, points to a rapid cessation of persecutions under the Trojan's rule. Eusebius explains it by the famous letter of Pliny the Younger to Trajan after which the emperor allegedly ordered to stop hunting for Christians [Eusebius Pamphilus, 2007, p. 127].

J. B. Segal, who studied the history of Edessa, formed a hypothesis that the legend could arise during the historical persecution of Decius in the middle of the III century [Segal, 1970, p. 82]. The text of the martyrdom of Sharbel and Barsamya, in its turn, was compiled under the bishopric of Rabbula of Edessa (d. 432/436). The texts of the Acts of Sharbel and Barsamya are abounded in inconsistencies [Cureton, 1864a, p. 64], which should be explained by the desire to emulate the Roman style of composing martyrdom acts.

At the same time, these acts reflect specific Syrian realities. Thus, the main gods, to whom people have to make sacrifices (because of the emperor's decree), were Semitic deities, not Roman, namely Bell and Nebu [Cureton, 1864c, p. 41]. The Babylonian cult of Bela or Baal is well known for the biblical books of Isaiah (46:1), Jeremiah (51:44) and especially the apocryphal chapters of prophet Daniel's book (Dan 14:1-32), whose protagonist makes fun of the ancient Semitic deity, saying that it can neither drink nor eat its oblations. The last argument echoes what Sharbel said during the interrogation. Babylonians also believed in another deity, Nabu, who was the god of writing. It seems like the authors of the Acts knew about him from the Old Testament. Isaiah mentioned this god (46:1) along with Baal and Marduk.

There is no information about the cult of the Roman emperor in the lives, so it is impossible to understand why the emperor strived to develop Middle Eastern religious cults that had not any ties with Rome. During this sacrifice, the local Christian bishop Barsamya converted Sharbel to Christianity. Then, the bishop presents a rather detailed description of Trinity's teachings [Cureton, 1864c, p. 43], which also proves that the dating of the plot is much later than the text of the acts is trying to claim because the earlier Christian Trinitarian doctrine was not so developed.

Next Barsamya's argument is historical. He refers to the plot which was also developed in the $4^{\text {th }}-5^{\text {th }}$ centuries. It is about the conversion to Christianity of Abgar V, who was originally a pagan and converted to Christianity after the sermon of the Apostle Thaddeus. If so outstanding people are converting to Christianity, this religion is at least permissible for existence in the state.

In the plot with Sharbel, we see how a narrative is created for the reader, a narrative, in which the priestly and secular nobility are also involved in persecuted Christianity. The acts of this martyr emphasize that the conversion of the priest to Christianity can be sincere and hard-won. This thought was important in the context of Edessa of the first half of the $\mathrm{V}$ century since its episcopal department was occupied by Rabbi Edessa, who was a son of a pagan priest, for a long time [Gibson \& Hock, 2017, p. 9].

Returning to the acts of the martyr, it is worthy to note that during the interrogation, the judge Lisany said that the fact that he does not cut off the former priest's ears, with which Sharil listened to gods' secrets and hands with which he made sacrifices, proves his great mercy. 
The judge was constantly appealing to the imperial power, the bearers of which venerated the gods whom the martyr despised [Cureton, 1864c, p. 47].

Acts of Sharbel reflect the main features of the Pagan-Christian polemic of the beginning of the $\mathrm{V}$ century. Unfortunately, it is difficult to determine which argument is indeed conveying the characteristics of such polemic in Syria, and which is just a trace of similar plots in Roman acts.

At the trial, Sharbel partially repeated Bishop Barsamaya's arguments, who converted him, that the pagans worship the creation of human hands, and these idols cannot do anything by their own. Another line of argumentation was focused on the criticism of pagan gods' morality. "For one had intercourse with boys, which is not right; and another fell in love with a maiden, who fled for refuge into a tree, as your shameful stories tell" [Cureton, 1864c, p. 54]. Unfortunately, it was impossible to find any unambiguous analogies in the Syrian pagan religion. It might have been the regular imitation of literary topos from the Roman Martyrs, in which the martyrs recalled the adventures of Zeus or Apollo, emphasizing the pagan gods' immorality and, therefore, the meaninglessness of veneration to them. Obviously, the local Middle East specificity is reflected in the question to Sharbel of whether it is possible to worship the heavenly bodies. The luminaries, after all, give light, unlike idols that cannot do anything. Sharbel replied that people have to honour the one who created all this [Cureton, 1864c, p. 57]. In response, the judge used another argument regarding the evaluation of the power of the deity. Christ was crucified and could not do anything with it, but Sharbel insisted that it was his voluntarily made sacrifice.

After Sharbel they arrested Christian Bishop Barsamya, the one who converted him. However, he escaped death thanks for the rapid cessation of persecution. Acts of Sharbel and Barsamya were crucial for the Christian urban myth of Edessa. Regarding this city, we can draw any firm conclusions only on the persecutions of the times of Diocletian. However, affected Christians were just poor villagers [Segal, 1970, p. 83] whereas either martyrs from the representatives of the nobility or the church elite were much more suitable for a full-fledged historical narrative. Perhaps real prototypes of Sharbel and Barsamya did not exist at all, but the plots of their torment, on the one hand, were arguments in the struggle against the remnants of paganism. On the other hand, they strengthened the class positions of the nobility. The famous Antiochian preacher, and later the Patriarch of Constantinople, John Chrysostom, also used the historical memory of the martyrs to fight paganism. In a sermon about the martyr Drosida, who was allegedly buried in a village near Antioch, Chrysostom exclaims: "When disputes with the pagans come to us $\langle\ldots>$ and they slander our faith, we will present to them the death of the martyrs" [John Chrysostom, 1896b, p. 557]. Regarding Drosida herself, it should be noted that the preaching of Chrysostom is the only mention of her in ancient texts, which is the answer why they relay local traditions about the martyrdom of a saint who was burned at the stake during one of the persecutions. If the author of the Acts of Sharbel tried to give a historical reference to the persecution of Trajan, then Chrysostom did not see any point in this. Thereby, he turned the whole story into a sermon of contempt for death and a kind of apology of Christianity to pagans.

The acts of Gurias, Simon (Shimon) and Aviv (Abibas) describe the real persecution of the times of Diocletian [Cureton, 1864b, p. 72] so they might have been based on some real written evidence that formed the basis of Acts that were created at the end of the IV century. However, the spearhead of popular historical memory associated with these saints is aimed at the event that occurred after their death. Gurias, Shamonas, and Abibas were considered the patrons of the city of Edessa, where two temples were erected in honour of them. The first one was built by Bishop Abraham in $346^{\text {th }}$ year on a mountain outside the walls of the city, and the second one a little later, under its western gate [Paykova, 1990a, p. 18]. In the oldest among preserved Syrian calendar of the end of the IV century, the $2^{\text {nd }}$ of September is called after St. Abibas, whereas the $15^{\text {th }}$ of November became the day of Gurias, Shamonas and Abibas [Paykova, 1990a, p. 18]. 
Another equally important motive for the existence of the historical memory of the martyrs was to support the Syrian identity and to protest against a lot of tragic Syrian realities.

Thus, in Syria of the period under review, was popular a legend about the events of the end of the IV century: "The story of Euthymia, her daughter Sofia, and the miracle that the confessors of Samonas, Gurias, and Abibas performed with them" [Paykova, 1990b]. The plot unfolds around the widow of Euthymia and her daughter Sophia that lived in Edessa when the Roman army came to their billets. One goth warrior decided to stay at Euthymia's house. After a while, he asked the mistress to give her daughter for him. The goth hid the fact that he had a wife in his homeland. The widow refused him several times, but due to the persistence of the goth, she was forced to accept his will [Paykova, 1990b, p. 95]. When the military threat receded, the goth decided to return to his homeland. The mother, still not trusting him, asked him to swear the oath of allegiance on the relics of the martyrs Shamonas, Gurias, and Abibas. He immediately agreed and did it with the words "As I will treat her, so the Lord (will) treat me" [Paykova, 1990b, p. 96].

Returning to his homeland with Sofia, the goth introduced her as a servant. Without knowing the local language, Sofia can hardly stand up for herself. When she gave birth to a child very similar to the goth, the first wife, out of jealousy, killed the child, but she, after a little time, was poisoned by maddened grieving mother. It should be noted that Sophia, as a positive character, did not murder out of revenge; she performed the act of a "God's judgment". Sophia decided that if the goth's wife will die from the poison left on the child's lips and carefully preserved by its mother, then she is guilty of the death of her child. If she would not die, it means that the child died by God's will [Paykova, 1990b, p. 97]. The wife died, and as a punishment, Sophia was walled up in a crypt, in the same place where the poisoned woman was buried. But here happens a miracle. Martyrs Samonas, Gurias, and Abibas, to with whom she prayed at night, transferred her to Edessa, straight to her native home. In a short while, the goth returned to Edessa, since the threat of a new Huns' invasion has arisen again. One of the locals recognized him, and after a trial, he was executed.

It should be noted that the names in the story are also tailored to ideological needs. For example, Euphemia in Greek means "enjoying good fame", whereas Sophia means "wisdom". Consequently, the authors of the story emphasized these features [Paykova, 1990a, p. 24]. The text is based on the antithesis of the good heroes (Euthymia and Sophia), and antiheroes (the goth and his wife). We consider this plot as a fixation in the people's memory of the city's hard times during army visits, which always placed a heavy burden on residents. These plots are also a kind of identity manifestation. The narrative clearly shows the interethnic conflicts of the Goths and the Syrians and also conveys the problem of the Syrians' estrangement from the Romans. It was times when they had no one to ask for help except their Edessian saints.

Another text that slightly reflects the historical memory of the Syrians in the context of interethnic relations is the work The History of Persian Martyrs, which belonged to Maruf, who was Bishop of Martiropolis. Maruf's work is interesting since it reflects the historical memory of Persian Syrians. There is almost no preserved information on them at all. Maruf learned the information about the ancient martyrs from the oral tradition.

One of the key plots of Persian Syrians' historical memory was related to the persecution under Shapur, which was associated with the confrontation of Persia and Rome, during which the Persians suspected Syrian Christians of supporting Rome. This persecution was not only religious but also economic, so the Syrian Christians (according to the text of the martyrdom written by Maruf, Mar Simon and the Comrades) were forced to pay a double war tax [Braun, 1915, s. 4]. This is one of the main reasons why this persecution is so salient in Syrians' historical memory. Materials collected by Maruf also prove that.

This persecution affected the Syrians' economic well-being. Thus, in the martyrdom Mar Simon and the Comrades, the persecution of the Syrians under Shapur is compared to the story of the righteous Job [Braun, 1915, s. 6], who did nothing wrong but suffered to prove loyalty to 
God. The Syrians also tried to show that there was no real reason for the persecution and they did nothing bad to the Persian state. Then Maruf recalls that there were also persecutions in Roman lands for 300 years, and says that as for him it does not make Persian persecution a kind of exceptional evil.

The hagiographic monument itself emphasizes that the Syrians tried to show their loyalty to the King of Kings. Moreover, they said that obeying secular rulers and honouring them is their religious duty [Braun, 1915, s. 10]. Maruf also welcomes those Persian authorities that were ready to compromise as well as Christians who did not sectarianize and did not bottle themselves in their teachings; thereby, they did not provoke a conflict. In the persecution of Mar Simon and his comrades, Maruf blames the Jews who allegedly slandered Mar Simon and the Christians before the Persian queen, which provoked the persecution.

Julian the Apostate (361-363) was considered the last persecutor of Christians in Roman Syria. Syrians' hate towards him was largely provoked by the transition of the Syrian city of Nisibin [Mar Ephrem of Nisibis, 2006, p. 107] to Persian authority [Mayboroda, 2011, p. 61]. His struggle with Christianity was not persecution as such (i. e. interrogations and urges to renounce the faith under the threat of execution). Indeed, the cases that the Syrians considered the martyrdom of the times of Julian technically looked like punishments for war crimes. For instance, the martyrdom of Juventinus and Maximinus; they were executed for violation of military discipline and failure to comply with orders, so formally they were not interrogated as Christians.

In a sermon dedicated to these Antioch martyrs, the Antiochian preacher John Chrysostom tries to emphasize the cunning of Julian, who tried to fight Christianity with more sophisticated methods than his predecessors. Thus, according to John, Julian ordered soldiers to sprinkle food on the Antioch market with the blood of sacrificial animals. Juventinus and Maximinus deprived those who refused from their property and executed them at night, so as not to demonstrate to all the greatness of Christian courage [John Chrysostom, 1896a, p. 622].

Chrysostom (as well as Socrates Scholasticus) also describes how Julian ordered to transfer the relics of the holy martyr Babila from Daphna (a suburb of Antioch) to another city [Socrates Scholasticus, 1996, p. 154]. The reason for the transfer was the request of the pagan priest of Apollo, who, due to the proximity to the relics of Babylon, could not focus on prophecy.

This persecution was not reflected in the Acts of the Martyrs in Syriac. However, the Greek text The History of the Person who Loved God of Theodoret of Cyrus, who gathered old stories about Syrian ascetics, reflects monks' opinion on the emperor Julian. These stories were passed by word of mouth and were recorded by Theodoret around the middle of the $\mathrm{V}$ century. Thus, the ascetic Julianius, learned that Emperor Julian was on a Persian campaign and was about to exterminate Christians upon his return, began to pray earnestly. The source further reports that "during the prayer, he heard a voice saying that the unclean and vile piglet had died" [Theodoret of Cyrus, 1996, p. 160]. This is probably one of the later legends that emerged in line with the Syrian tradition and makes Julian one of the main antiheroes of historical memory.

The popularity of the places of martyrs' veneration is also an important topic. The grave of the martyr Drosida and the tomb of the martyr Babylon have been already mentioned above, but also we have a bit of interesting information about the martyr Elpidius' veneration in the Syrian city of Harran. Thus, his memorial day was celebrated on a ninth day after May calends. The relics of the saint were preserved in a temple built on the site of the house of biblical Abraham and it is necessary to note that the memory of the martyr levelled the memory of the forefather who lived in these parts. Even hermits came down from their caves to the city for the holiday of Elpidius, and it was the only exception along with Easter [Pomyalovsky, 1889, p. 133]. Thereby, the relics of martyrs became objects of popular veneration in the period between the IV and V century and displaced many other plots of the historical memory of its regions. 


\section{Conclusions}

The end of the IV century and the first half of the $\mathrm{V}$ century is the period when most of the stories about the martyrs were systematized. Besides the relative economic and political stability, this period is also characterized by the activities of many prominent figures of the Syrian Christian church and Syrian intellectuals, among whom were Rabbula of Edessa, Iba of Edessa, Theodoret of Cyrus, Maruf of Manferkat and others.

The active systematization of historical knowledge about the Syrian martyrs contributed to both the establishment of the local Syrian identity and the elevation of the cultural significance of the region on an empire scale, as part of the work was either written in Greek or was promptly translated into it.

The historical memory of the Syrians is an interesting indicator reflecting the existing ethnic, political, religious and (to a certain extent) economic contradictions that existed in Syrian society in the first half of the $\mathrm{V}$ century.

Acts of martyrs reflect the religious confrontation of Christianity and paganism. Many of them contain direct dialogues between Christians and pagans, where the heroes articulate arguments relevant for the period between the end of the IV century and the beginning of the $\mathrm{V}$ century. The authors of martyrdom acts and sermons often used plots from martyrs' lives as a basis for moralizing or as a tool in religious controversy. Ethnic and political contradictions are reflected in Syrian relations with representatives of other peoples and states. It is possible to find anti-Jewish motives both in the above-mentioned texts and legends about the Syrian martyrs in Persia. According to these legends, the Jews persuaded the wife of King of Kings to persecute Christians. In the legend of the miracle from the relics of martyrs from Guria, Shimon and Abibas, one can feel grievances regarding the permanent stay of Roman troops, which placed a heavy burden on the shoulders of residents.

Plots related to Christian Syrians in Persia reflect economic problems in Syrian historical memory. Among them is the history of the double military tax that existed during the Persian war with Rome. Such historical plots were intended to explain to Syrian artisans and merchants in Persia how they should interact with the local authorities. Thus, they had to emphasize loyalty to local authorities and avoid showing any gestures of reverence for Rome, which was in almost permanent war with Persia.

The last period of persecution in Roman Syria took place during the reign of Emperor Julian the Apostate. This period had many specific features and was not persecution in the classical sense, since the victims Juventin and Maximin were technically punished for violating military orders. Nevertheless, loads of folklore stories about Julian were reflected in Julian Romance, as well as in several Syrian hagiographic texts. In addition to efforts on restoring paganism, Julian was associated with the signing of unfavourable for Rome treaty with the Persians, according to which the Syrian city of Nisibis should have come under the rule of the latter. Thereby, in the historical memory of the Syrians, the image of Julian acquired an increasingly gloomy shade of not only an apostate and persecutor but also a bad ruler, whose actions changed the life of part of the Syrians for the worse.

To sum up, the historical memory of the Syrians, with all its ambiguity and inconsistencies, was a tool to explain (and often to justify) the current state of affairs. If necessary, it could give strong arguments in theological and political disputes and help to enhance ethnic and cultural identity.

\section{Research prospects}

It is interesting to trace other aspects of the historical memory of the Syrians. Among them are the memory of The Kingdom of Osroene, biblical images in historical memory, and narratives about the presence of Julian the Apostate in Syria.

\section{Acknowledgements}

My thanks to Maxim Panin, Pavel Mayboroda and Elena Radzikhovskaya for their help with this study! 


\section{REFERENCES}

Bolotov, V. V. (1910). The Lection about the History of Ancient Church (Vol. 2). St. Petersburg. (In Russian).

Braun, O. (Trans.). (1915). Mâr Simon und Genossen. In Ausgewählte Akten persischer Märtyrer. Mit einem Anhang: Ostsyrisches Mönchsleben Aus dem Syrischen (S. 5-58). Kempten: J. Kösel. (In German).

Cureton, W. (Trans.). (1864a). Martyrdom of Barsamya, The Blessed Bishop of The City Edessa. In Ancient Syriac Documents (pp. 63-72). London: Williams \& Norgate.

Cureton, W. (Trans.). (1864b). Martyrdom of Habib the Deacon. In Ancient Syriac Documents (pp. 72-85). London: Williams \& Norgate.

Cureton, W. (Trans.). (1864c). The Acts of Sharbel, Who Had Been the High Priest of Idols, and Was Converted to the Confession of the Christian Religion in Christ. In Ancient Syriac Documents (pp. 41-62). London: Williams \& Norgate.

Eusebius Pamphilus. (2007). Ecclesiastical History. St. Petersburg. (In Russian).

Gibson, C. A., \& Hock, R. (Eds.). (2017). The Rabbula Corpus: Comprising the Life of Rabbula, His Correspondence, a Homily Delivered in Constantinople, Canons, and Hymns: With Texts in Syriac and Latin. (R. R. Phenix Jr. \& C. B. Horn, Tans.). Atlanta: SBL Press.

Ivanovici, V. (2013). Competing Paradoxes: Martyrs and the Spread of Christianity Revisited. Studia Patristica, LXII, 231-244.

John Chrysostom. (1896a). A Commendable Conversation about the Holy Martyrs Juventinus and Maximinus, Who Suffered under Julian the Apostate. In Works of John Chrysostom, Archbishop of Constantinople (Vol. 2, pp. 618-623). St. Petersburg. (In Russian).

John Chrysostom. (1896b). Praise to the Holy Great Martyr Drosida, and the Memory of Death. In Works of John Chrysostom, Archbishop of Constantinople (Vol. 2, pp. 730-741). St. Petersburg. (In Russian).

Lebedev, A. P. (2006). The Era of Persecution of Christians and the Establishment of Christianity in the Greco-Roman World under Constantine the Great. St. Petersburg. (In Russian).

Mar Ephrem of Nisibis. (2006). Julian's Cycles. (A. Muraviev, Trans.). Moscow: Heritage of the Orthodox East Foundation; Fraternity of St. Gregory Palamas; Infores Publishing House. (In Russian).

Mayboroda, P. A. (2011). The Christian Writers of IV-V Centuries about Julian the Apostat. 'E $\sigma \chi \alpha \dot{\alpha} \omega \varsigma$ - Eschatos, 1, 55-67. Odesa. (In Russian).

Meshcherskaya, Ye. N. (1984). The Legend about Abgar - Text of Early Byzantium Literature. Moscow: Nauka. (In Russian).

Paykova, A. V. (1990a). Legends and Sagas in the Texts of Syrian Hagiography. Palestinian Digest, 30(93). (In Russian).

Paykova, A. V. (Trans.). (1990b). The Story of Euthymia, Her Daughter Sofia, and the Miracle that the Confessors Samonas, Gurias, and Abibas Performed with Them. Palestinian Digest, 30(93), 95-100. (In Russian).

Pomyalovsky, I. V. (Ed. \& Trans.). (1889). The Pilgrimage to the Holy Places of the End of the IV Century. Orthodox Palestinian Digest, 20, 103-172. (In Russian).

Ruinart, T. (Ed). (1731). Passio Sancti Bonifacii Martyris. In Acta Martyrum (pp. 325-332). Veronae: Typogaphia Tumermaniana. (In Latin).

Segal, J. B. (1970). Edessa: "The Blessed City". Oxford: The Clarendon Press.

Socrates Scholasticus. (1996). Ecclesiastical History. (I. V. Krivushin, Trans.). Moscow. (In Russian). Theodoret of Cyrus. (1996). History of Persons Who Love God. (A. I Sidorov, Trans.). Moscow. (In Russian). 


\title{
Vodko Vladyslav I.
}

PhD Student, Faculty of History and Philosophy

Odesa I. I. Mechnikov National University

13, Yelyzavetynska Street, 65029, Odesa, Ukraine

E-mail: vladislavvodko17@gmail.com

ORCID: https://orcid.org/0000-0002-1492-4058

Article arrived: 30.06 .2020

Accepted: 12.10 .2020

\section{ЕПОХА МУЧЕНИКІВ В ІСТОРИЧНІЙ ПАМ'ЯТІ СИРІЙЦІВ-ХРИСТИЯН КІНЦЯ IV - ПЕРШОЇ ПОАОВИНИ V СТОАІТТЯ}

\author{
Водько ВАадислав Ігорович \\ аспірант, факультет історії та філософії \\ ОАеський національний університет імені I. I. Мечникова \\ вул. Єлизаветинська, 13, ОАеса, 65029 \\ E-mail: vladislavvodko17@gmail.com \\ ORCID: https://orcid.org/0000-0002-1492-4058
}

Метою цієї роботи є досліАження характеру історичної пам'яті сирійців-християн про епоху ранньохристиянських мучеників. АосліАжуваний період кінця IV - першої половини V ст. $є$ часом становлення християнства як Аержавної релігії в Римській імперії. Ми спробували встановити, яким чином історична пам'ять про мучеників відображає особливості культурної ідентичності сирійців, а також їне ставлення до представників інших етнічних груп. Новизна статті полягає в тому, що в ній уперше сереА вітчизняних досліАжень проаналізовано історичну пам'ять сирійців про епоху мучеників і запропоновано систематичний огляд основних соціальних та іАеологічних функцій, які були притаманні ій. Зроблено ряд висновків про характер сирійської іАентичності розглянутого періоду. АосліАжена християнсько-язичницька полеміка в Сирії крізь призму історичної пам'яті. У піАсумку були отримані такі висновки. Ера ранньохристиянських мучеників у сирійській історичній пам'яті виконувала низку іАеологічних і культурно-соціальних функцій. Історична пам'ять про мучеників була важливою рисою релігійної ілентичності сирійців, які жили на території двох ворогуючих держав: Персії та Риму. Представники сирійської церкви розглянутого періоду піАкреслювали, що їхня церква творилася подвигами багатьох мучеників, що ставало аргументом у богословських суперечках і допомагало зміцнитися регіональній ідентичності представників антіохійської школи богослов'я, яка в 30-40-х рр. V ст. переживала важкі часи внаслідок звинувачення в ересі. Історична пам'ять про епоху мучеників віАображає актуальні Аля цього періоду питання полеміки християн з язичництвом, що поступово відмираАо. У текстах, які $є$ рецепцією епохи мучеників, часто віАображені певні етнічні протиріччя та соціально-економічні проблеми. Так, у пересліАуванні сирійців-християн у Персії сирійці звинувачували іудеїв, а перський цар піА час гоніння на сирійців-християн збільшуе Аля них податки. Передаючи свідчення про минуле гоніння в Персії, автори намагаються пояснити нерелігійні причини гоніння та підспудно надати певну модель поведінки, яка би дозволила уникнути подібних труднощів Аля християнської громади в майбутньому.

КАючові слова: Римська Сирія, пізня античність, раннє християнство, мученики, історична пам'ять.

\section{СПИСОК ВИКОРИСТАНИХ АЖЕРЕ}

Болотов, В. В. Аекции по истории Аревней церкви: в 4-х т.; т. 2: История церкви в период Константина В. / под ред. Бриллиантова А. СПб.: Тип. М. Меркушева, 1910. 474 с.

Евсевий Памфил. Церковная история. СПб.: Амфора, 2007. 491 с.

Иоанн 3^атоуст. Похвальная беседа о святых мучениках Иувентине и Максимине, пострадавших при Юлиане Отступнике. Творения святаго отиа намего Иоанна Златоуста, архиепископа Константинопольского, в русском переводе: в 12-ти т.; т. 2. СПб., 1896. С. 618-623. 
Иоанн 3^атоуст. Похвала святой великомученице Аросиде, и о памятовании смерти. Творения святаго отиа нашего Иоанна Златоуста, архиепископа Константинопольского, в русском переводе: в 12-ти т.; m. 2. СПб., 1896. С. 730-741.

История о Евфимии, Аочери Софии, и о чуде, которое совершили с ними исповедники Шамуна, Гурия и Хабиба / пер. А.В.Пайковой. Палестинский сборник. Вып. 30 (93). 1990. С. 95-100.

Аебедев А. П. Эпоха гонений на христиан и утвержление христианства в грекоримском мире при Константине Великом. СПб.: ИзАательство Олега Абышко, 2006. 352 с.

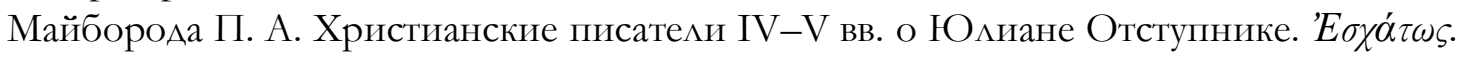
№ 1. OАecca, 2011. C. 55-67.

Мар Афрем Нисибинский (прп. Евфем Сирин). Юлиановский цикА / пер. А. Муравьева; научн. ред. А. А. Поспелов. М.: ФонА «Наследие Православного Востока»; Братство святителя Григория Паламы; Инфорес, 2006. 240 с.

Мещерская Е. Н. Аегенда об Авгаре - раннесирийский Аитературный памятник. М.: Наука, 1984. 252 с.

Пайкова А. В. Аегенды и сказания в памятниках сирийской агиографии. Палестинский сборник. Вып. 30 (93). 1990. 143 с.

Паломничество по Святым местам конца IV века / изАание, перевод и объяснение И. В. Помяловский. Православный палестинский сборник. Вып. 20. 1889. С. 103-172.

Сократ Схоластик. Церковная история / перевод под реА. И. В. Кривушина. М.: РОССПЭН, 1996. 368 с. 1996. $446 \mathrm{c}$.

Феодорит Кирский. История боголюбцев / пер. А. И. Сидорова. М.: Паломник,

Ivanovici V. Competing Paradoxes: Martyrs and the Spread of Christianity Revisited. Studia Patristica. Vol. LXII. 2013. pp. 231-244.

Mâr Simon und Genossen. Ausgewählte Akten persischer Märtyrer. Mit einem Anhang: Ostsyrisches Mönchsleben Aus dem Syrischen / übers. von O. Braun. Kempten: J. Kösel, 1915. S. 5-58.

Martyrdom of Barsamya, The Blessed Bishop of The City Edessa. Ancient Syriac Documents / trans. by William Cureton. London: Williams and Norgate, 1864. pp. 63-72.

Martyrdom of Habib the Deacon. Ancient Syriac Documents / trans. by William Cureton. London: Williams and Norgate, 1864. pp. 72-85.

Passio Sancti Bonifacii Martyris. Acta Martyrum: P. Theodorici Ruinart opera ac studio collecta, selecta atque illustrate. Veronae: Typogaphia Tumermaniana, 1731. pp. 325-332.

Segal J. B. Edessa: "The Blessed City". Oxford: Clarendon Press, 1970. xviii + 308 p.

The Acts of Sharbel, Who Had Been the High Priest of Idols, and Was Converted to the Confession of the Christian Religion in Christ. Ancient Syriac Documents / trans. by William Cureton. London: Williams and Norgate, 1864. pp. 41-62.

The Rabbula Corpus: Comprising the Life of Rabbula, His Correspondence, a Homily Delivered in Constantinople, Canons, and Hymns: With Texts in Syriac and Latin / English translations, notes, and introduction by Robert R. Phenix Jr. and Cornelia B. Horn; General Editors Craig A. Gibson and Ronald Hock. Atlanta: SBL Press, 2017. 750 p.

Стаття надійшла Ао редакції: 30.06.2020

Схвалено Ао Аруку: 12.10.2020 